\title{
STOCK DISCRIMINATION OF TWO INSULAR POPULATIONS OF DIPLODUS ANNULARIS (ACTINOPTERYGII: PERCIFORMES: SPARIDAE) ALONG THE COAST OF TUNISIA BY ANALYSIS OF OTOLITH SHAPE
}

\author{
Mouna TROJETTE ${ }^{1 *}$, Abderraouf BEN FALEH ${ }^{1}$, Manel FATNASSI ${ }^{1}$, Bochra MARSAOUI ${ }^{1}$, \\ Nour El Houda MAHOUACHI ${ }^{1}$, Abdellah CHALH ${ }^{2}$, Jean-Pierre QUIGNARD ${ }^{1,3}$, \\ and Monia TRABELSI ${ }^{1}$ \\ ${ }^{1}$ Unité de Biologie Marine, Faculté des Sciences, Université Tunis El Manar, Tunis, Tunisie \\ ${ }^{2}$ Unité de génétique des populations et ressources biologiques, Faculté des Sciences, Université Tunis El Manar, \\ Tunis, Tunisie \\ ${ }^{3}$ Laboratoire d'Ichtyologie, Laboratoire d'Ichtyologie, Université Montpellier II, Montpellier cedex, France
}

Trojette M., Ben Faleh A., Fatnassi M., Marsaoui B., Mahouachi N.H., Chalh A., Quignard J.-P., Trabelsi M. 2015. Stock discrimination of two insular populations of Diplodus annularis (Actinopterygii: Perciformes: Sparidae) along the coast of Tunisia by analysis of otolith shape. Acta Ichthyol. Piscat. 45 (4): $363-372$.

Background. The annular seabream, Diplodus annularis (Linnaeus, 1758), is the most common sparid fish in the Mediterranean Sea. This species is widespread in Tunisia. Despite their economic importance, due to their excellent white and delicate flesh (demersal fish) and their significant size, few studies have hitherto focused on stock discrimination and on the fisheries management. The goal of this research was to evaluate the stock structure of $D$. annularis for two Tunisian insular populations based on the otolith shape, using different statistical approaches. Materials and methods. The specimens of Diplodus annularis were collected during five months ranging from May through September 2014 at two sites: Djerba and Kerkennah. In total, 120 fish were collected from the two sites: 60 specimens of each population (30 males and 30 females) and were included in different statistical analyses. The Fourier coefficients were determined to evaluate the degree of similarity in the otoliths and detect the reciprocal variability.

Results. By comparing the two studied populations, we revealed statistical significant differences, an asymmetry (left-right), of otoliths $(P<0.05)$. In the same population, symmetry (left-right) was detected for the males, females of Kerkennah, and females of Djerba. However, an asymmetry was detected only for the males of Djerba. Also, sexual dimorphism was observed only for the Djerba population.

Conclusion. The comparison of the otolith morphology of the two populations showed a clear difference in shape and a left-right asymmetry of otoliths. This asymmetry indicates that the two populations belong to different stock of fish. The stocks characterization is considered as an important tool for fisheries management. Further studies are necessary to determine the origin of the otolith shape differences and whether they are related only to environmental conditions or a genetic basis may also be responsible.

Keywords: fish, fisheries management, symmetry, asymmetry, shape, Djerba, Kerkennah

\section{INTRODUCTION}

Seabreams, representing the family Sparidae, are widespread in the Mediterranean Sea and constitute an important fishery resource along this coast (Gordoa and Molí 1997). They have global distribution and occur in coastal waters thus sustaining important recreational and commercial fisheries (Fischer et al. 1987). The species representing this family are distributed in a wide variety of marine habitats, from rocky to sand bottoms, at depths ranging from 0 to $500 \mathrm{~m}$. They are more common, however, at depths not exceeding $150 \mathrm{~m}$ (Gonçalves 2000, Gomes et al. 2001, Sousa et al. 2005, Ribeiro et al. 2006).

The annular seabream, Diplodus annularis (Linnaeus, 1758), is the most common sparid fish in the Mediterranean Sea (Osset et al. 2005). Indeed, this species is distributed from the Gulf of Biscay to Gibraltar, around Madeira and Canary Islands, as well as in the Mediterranean and the Black Sea (Jardas 1996, Summerer et al. 2001). The habitat of this

\footnotetext{
* Correspondence: Dr M. Trojette, Unité de Biologie Marine UR 13 ES 36, Faculté des Sciences de Tunis, Université Tunis El Manar, Tunis, Tunisie, phone: +216 50612 051, e-mail: (MT) mayna_bio@hotmail.com, (ABF) benfalahabdelraouf@yahoo.fr, (MF) manel.ft@gmail.com, (BM) marsaouibochra@gmail.com, (NHM) nourelhoudamahouachi4@gmail.com, (AC)abdellah.chalh@gmail.com, (J.PQ)qjp2@wanadoo.fr, (MT)atherina2002@yahoo.fr.
} 
fish is restricted mainly to Posidonia- (Harmelin-Vivien et al. 1995) and Zostera (Matic-Skoko et al. 2004) beds.

Previous studies of Diplodus annularis focused on the morphological characteristics (Tortonese 1975), life history (de la Paz 1975), age and growth (Gordoa and Molí 1997, Pajuelo and Lorenzo 2001, 2002, Matic-Skoko et al. 2007, Girardin unpublished*), as well as the feeding (Bell and Harmelin-Vivien 1983, Rosecchi 1987, Pita et al. 2002). Also the morphology of Diplodus annularis otoliths were studied by some authors (Kinacigil et al. 2000, Pajuelo and Lorenzo 2002, Lychakov and Rebane 2000, Alós et al. 2010, Ayyildiz et al. 2014). However, no studies regarding stock discrimination of $D$. annularis have been conducted in comparison with other species belonging to the family Sparidae (see Kinacigil et al. 2000, Pajuelo and Lorenzo 2001, Arculeo et al. 2003, Correia et al. 2011).

The otoliths generally remain stable over time, unlike other calcified structures like scales (Mérigot et al. 2007, Morat et al. 2008). The analysis of otoliths characteristics offers a unique potential for reconstitution, a temporal resolution ranging from days to years, at a time, the environmental parameters effects and traits of fish life (Fablet 2012). In addition, the otoliths are also likely to keep record of the depths at which fish occur (Morat unpublished**).

The otolith shape is species specific (Sadighzadeh et al. 2014). The outer shape of fish otoliths has been used in identification of the species (Nielsen et al. 2010) and/ or fish stock (Begg and Brown 2000, Cardinale et al. 2004, Ponton 2006). The three-otolith pairs in teleost have a large morphological variability (Lombarte and Cruz 2007). This variability is especially true for the saccular otolith (sagitta) associated with the inner ear organ, sacculus, in non-ostariophsean fishes (Platt and Popper 1981, Lombarte and Cruz 2007). The morphological differences affect both the size and shape of the otoliths (Paxton 2000).

The goal of this study was to evaluate the stock structure of Diplodus annularis — which is probably influenced by physical, biological, and ecological processes - by using otolith shape analysis. The case study was carried out on two Tunisian insular populations (Djerba and Kerkennah) using different statistical approaches.

\section{MATERIALS AND METHODS}

Sample collection. The fishing of the annular seabream, Diplodus annularis, was carried out by specific gillnets targeting this particular species. The gillnets consist of a piece of netting, with a rectangular shape, of 60 to $80 \mathrm{~m}$ in length and 33 to 300 meshes of height. In this type of selective mesh nets ranging from 22 to $26 \mathrm{~mm}$ (square measure), the specimens become entangled at the level of the gills. The fishing gear is composed by fixed sections end to end with an average of 14 pieces. It is wedged on the bottom from the sunset to dawn. The gillnets were operated by coastal boats from 5 to $13 \mathrm{~m}$ in overall length, on average.

The specimens of Diplodus annularis were collected during five months, from May to September 2014, at two sites: Djerba and Kerkennah. In total, 60 specimens (30 females and 30 males) were sampled from each site (as shown in Fig. 1). Each fish was measured and dissected. Only the total length and the total weight were taken into account (Table 1).

Otolith extraction. The otolith extraction protocol is based on several steps (Trojette unpublished ${ }^{* * *}$ ). Firstly, we cut horizontally the upper bone of the fish head, with a very sharp knife blade. After that, we extracted the fish brain from the head to reach the otoliths located in the skull cavities. Finally, the otoliths were removed with forceps, and once removed, the left and right otoliths were cleaned with distilled water, dried, wrapped in cotton wool, and stored in Eppendorf tubes for further processing.

Image and shape analyses. The otoliths were photographed by a digital camera (Samsung PL210 with the resolution of 14.2 megapixels and optical zoom $10 \times$ ) on a

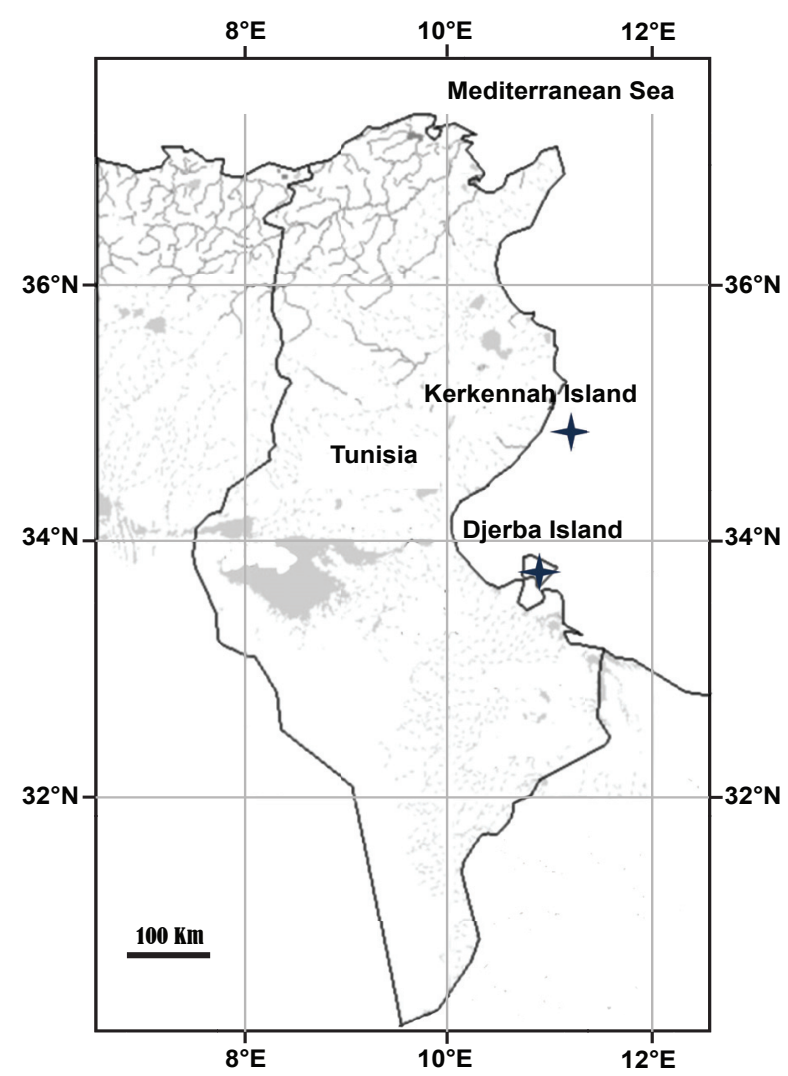

Fig. 1. Sampling sites (marked with four-pointed star) of the annular seabream, Diplodus annularis, along the coast of Tunisia

\footnotetext{
* Girardin M. 1978. Les Sparidés (Pisces, Teleostei) du Golfe du Lion-Ecologie et Biogéographie. Thèse de doctorat. Université des Sciences Techniques du Langudoc, Montpellier, France.

** Morat F. 2011. Influence des apports rhodaniens sur les traits d'histoire de vie de la sole commune (Solea solea): Apports de l'analyse structurale et minéralogique des otolithes. Thèse de doctorat en Océanographie. Université Marseille, France.

*** Trojette M. 2012. Etude otolithométrique comparée de trois populations d'une espèce de Scorpénidés (Scorpaena porcus) dans le milieu marin et insulaire de Tunisie. Thèse. Faculté des sciences de Tunis, Université Tunis El Manar, Tunisie.
} 
Table 1

Length and weight of annular seabream, Diplodus annularis, specimens from different sampling sites in Tunisia

\begin{tabular}{lcccc}
\hline \multirow{1}{*}{ Parameter } & \multicolumn{2}{c}{ Sampling site } \\
\cline { 2 - 5 } & Djerba & Djerba & Kerkennah \\
\hline Sex & Males & Females & Males & Ferkennah \\
Number of fish & 30 & 30 & 30 & $117.46 \pm 5.6$ \\
Total length $[\mathrm{mm}]$ & $129.86 \pm 8.53$ & $126.86 \pm 8.14$ & $28.27 \pm 4.18$ & $28.41 \pm 3.69$ \\
Total weight $[\mathrm{g}]$ & $31.06 \pm 4.07$ & $31.94 \pm 4.38$ & 2.15 \\
\hline
\end{tabular}

The values are mean \pm standard deviation (based on 5 month period.

dissecting microscope after observation. The image analysis on a computer screen allowed us to evaluate each image and store it in a database. The photos of all otoliths were processed by Adobe Photoshop CS6 (Fig. 2). Subsequently the images were processed by the Shape Ver. 1.3 software which would create 20 harmonies for each otolith (each otolith represents an individual). Each harmony was composed by four coefficients, so called the Fourier Coefficients (A, B, C, and D) corresponding to the values of the projection of the binary image on the axes $X$ and $Y$ (Kuhl and Giardina 1982), resulting in 80 coefficients per individual. The most useful method for shape analysis of otoliths is based on Fourier descriptors (Duarte-Neto et al. 2008). Recently, other representations such as wavelets (Chuang and Kuo 1996) and multi-scale curvature (CSS) (Mokhtarian and Mackworth 1986) have been studied in the analysis of calcified structures forms (Parisi-Baradad et al. 2005).

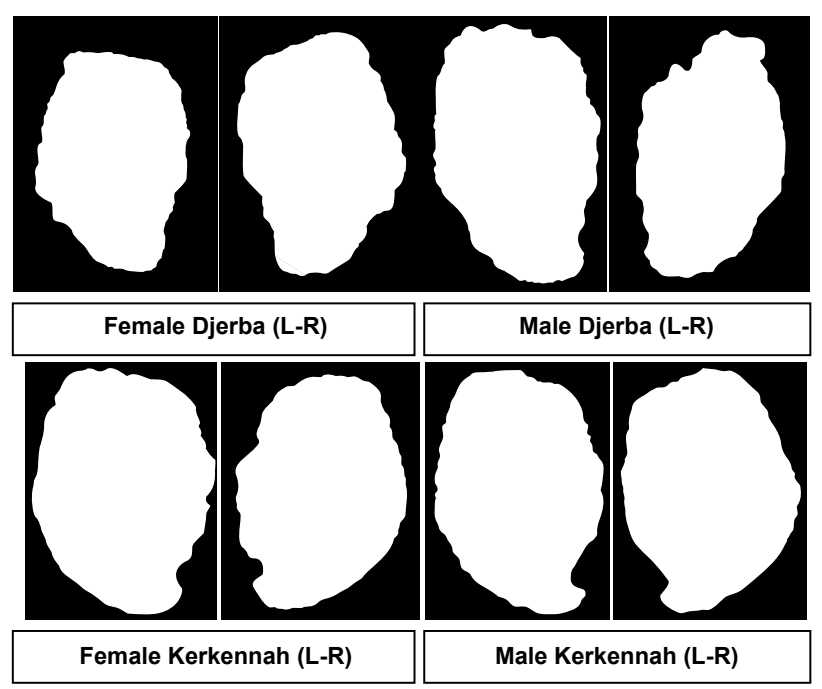

Fig. 2. Photographs of the otoliths (left-right) of annular seabream, Diplodus annularis, processed with the aid of the Photoshop software

Statistical methods. The morphological variation in individuals is based on statistical analysis of the parameters from the developments in Fourier series. The mathematical analyses of the otolith shape are achieved by Elliptic Fourier Analysis (EFA). This technique describes the silhouette called Harmonic. Each harmonic is characterized by four Fourier Coefficients (A, B, C, and D) which cal- culates the Fourier Power (FP), the percentage of Fourier Power (FP\%), and the cumulative percentage of the Fourier Power ( $\mathrm{FP}_{n} \%$ cumulative). The respective formulas (Crampton 1995) are provide below:

$$
\mathrm{FP}=\frac{A_{n}^{2}+B_{n}^{2}+C_{n}^{2}+D_{n}^{2}}{2}
$$

where $A_{n}, B_{n}, C_{n}, D_{n}$ are the Fourier Coefficients.

$$
\begin{gathered}
\mathrm{FP}=\left(\frac{\mathrm{FP}}{\sum \mathrm{FP}}\right) \times 100 \\
\mathrm{FP}_{n} \%_{c}=\sum_{1}^{n} \mathrm{FP}_{n} \%
\end{gathered}
$$

The cumulative percentage of Fourier Power ( $\left.\mathrm{FP}_{n} \%\right)$ is calculated in order to determine the necessary and sufficient number of harmonics for better construction of the silhouette of the otolith (Crampton 1995). This is obtained for a value equal to $99.99 \%$ of the cumulative percentage of the mean Fourier Power $\left(\mathrm{FP}_{n} \%\right)$. The results were fed into Microsoft Excel and processed. To assess the differences between different batches of otoliths, we performed multivariate analyses that enable the processing of all the otolith parameters at the same time. The data matrix was subjected to a Discriminant Function Analysis (DFA), to illustrate the differences and similarities between the observed groups and optimize the variability existing between them. The DFA was determined successively, while the factorial graphic designs allow visualizing individuals or variables. Various indicators and tests are also used in order to estimate the reliability of our results. These analyses were performed using 'XLSTAT' (2007) software.

Statistical tests. The statistical analysis of the otolith shape is achieved by the Elliptic Fourier Analysis (EFA) describing the shape of the otolith. To have the best possible otolith shape, the percentage of Fourier Power was calculated to determine the number of harmonics necessary and sufficient. For this reason, this number was fixed at 20 . A total of 180 replicates were obtained (60 observations the for each study site). 
Multivariate analysis was performed for the treatment of all otolith synchronous parameters. The data matrix was previously subjected to DFA, which detect similarities and differences between the two sets of otoliths. The results were subsequently interpreted by the STAT EXCEL 2007 software and provide the following different statistical tests.

\section{RESULTS}

The Wilks' Lambda test (Rao approximation) performed on the otoliths (see Fig. 2) revealed the presence of statistically significant differences between the two populations studied $(P<0$. 0001) (Table 2).

Wilks' Lambda test of the distance approximation between populations of annular seabream, Diplodus annularis (Rao approximation)

\begin{tabular}{lc}
\hline \multicolumn{1}{c}{ Parameter } & Value \\
\hline Lambda & 0.0192 \\
$F$ (Observed value) & 1.5776 \\
$F$ (Critical value) & 1.1282 \\
DDL1 & 539 \\
DDL2 & 1116 \\
$P$-value & $<0.0001$ \\
Alpha & 0.05 \\
\hline
\end{tabular}

The matrix of Mahalanobis distances described the distance between the left and right otoliths of each population (Djerba and Kerkennah). It also described the distance between the left otoliths and the right ones of both populations (left Djerba-left Kerkennah and right Djerba-right Kerkennah) (Table 3). Indeed, the respective left-right distances between the otoliths (L-R) were 7.56 and 15.45 for Djerba (female and male) and 8.44 and 8.80 for Kerkennah (female and male), indicating that the Mahalanobis distance between the individuals for the two populations was similar except the males of Djerba. Turning to the Mahalanobis distances between the otoliths of the two populations, the distances between Kerkennah-right-female versus Djerba-right-female and Kerkennah-right-male versus Djerba-right-male amounted to 13.02 and 17.63 , respectively. Also, the distance between Kerkennah-left-female versus Djerba-left-female and between Kerkennah-left-male versus Djerba-left-male were 10.53 and 14.99 , respectively (Table 3).

With the exception of one case (otolith left-right male Djerba), these results showed that the distance between the left otoliths and the right ones of both populations was more important than the distance between left-right otoliths within each population.

The Mahalanobis and Fisher distances gave the same results. In fact, the Fisher distance between the otoliths (left-right) for Djerba (female and male) were 0.99 and 2.03, respectively and for Kerkennah (female and male) were 1.12 and 1.17, respectively. The highest distances were for the males of Djerba, followed by males, females of Kerkennah and females of Djerba. By comparing the two populations (Djerba and Kerkennah), the Fisher distance Kerkennah-right-female versus Djerba-right-female and Kerkennah-right-male versus Djerba-rightmale amounted to 1.74 and 2.35, respectively. The Fisher distance between Kerkennah-left-female versus DjerbaLeft-female and Kerkennah-left-male versus Djerbaleft-male was 1.38 and 1.97 , respectively (Table 4). The above-mentioned results showed that the most important distances were those detected between the otoliths of Djerba males and Kerkennah males).

In the context of a comparison within the same population, the $P$-value (left-right) of Fisher distance was highly statistically significant $(P<0.0001)$ for the males originally from Djerba Island (case of left-right asymmetry) while the $P$-values were not significant $(P>0.05)$ for the females of Djerba $(P=0.5006)$, the males and females of Kerkennah (male $P=0.1947$, female $P=$ 0.2609 ) (case of left-right symmetry) (as shown in Table 4 below the diagonal). In another hand, sexual dimorphism was observed only in the Djerba population: (for female and male left, $P=<0.0001<0.05$ ), (for female and male right, $P=<0.0023<0.05$ ). It can be concluded that in Djerba population, dimorphism was more significant for left otoliths. However, no difference was detected between males and females of the Kerkennah popula-

Table 3

Matrix Mahalanobis distances between otoliths representing both sexes and two sides of otoliths for two sampling sites of annular seabream, Diplodus annularis

\begin{tabular}{|c|c|c|c|c|c|c|c|c|}
\hline & ○ RD & ○RK & Q LD & OLK & $\delta^{-1} \mathrm{RD}$ & ${ }^{\lambda} \mathrm{RK}$ & $\partial^{\lambda} \mathrm{LD}$ & $\partial^{\lambda} \mathrm{LK}$ \\
\hline qRD & 0 & 13.0233 & 7.5665 & 12.2499 & 13.0281 & 12.7440 & 10.5535 & 10.2469 \\
\hline qRK & & 0 & 18.7084 & 8.4412 & 19.1323 & 7.4403 & 13.0220 & 10.0027 \\
\hline qLD & & & 0 & 10.5329 & 14.1883 & 17.1066 & 17.0788 & 10.0873 \\
\hline OLK & & & & 0 & 16.2943 & 11.0658 & 14.0500 & 7.5216 \\
\hline${ }^{1} \mathrm{RD}$ & & & & & 0 & 17.6341 & 15.4517 & 13.5998 \\
\hline${ }^{\circledR} \mathrm{RK}$ & & & & & & 0 & 11.5311 & 8.8098 \\
\hline$\delta^{\lambda} \mathrm{LD}$ & & & & & & & 0 & 14.9934 \\
\hline$\sigma^{\lambda} \mathrm{LK}$ & & & & & & & & 0 \\
\hline
\end{tabular}

$\mathrm{RK}=$ right otolith from Kerkennah, $\mathrm{LK}=$ left otolith from Kerkennah, $\mathrm{RD}=$ right otolith from Djerba, $\mathrm{LD}$ = left otolith from Djerba); the underscored values indicate the distance between the two populations / the the values in bold indicate the distance within each population. 
Table 4

The test of Fisher distances between sexes and two sides of otoliths for two sampling sites (above diagonal) and $P$-values (below diagonal) for annular seabream, Diplodus annularis,

\begin{tabular}{|c|c|c|c|c|c|c|c|c|}
\hline & $q \mathrm{RD}$ & PRK & QLD & qLK & ${ }^{\wedge} \mathrm{RD}$ & ${ }^{\lambda} \mathrm{RK}$ & $\partial^{\lambda} \mathrm{LD}$ & $\delta^{\lambda} \mathrm{LK}$ \\
\hline q RD & $*$ & $\underline{1.7411}$ & $\underline{\underline{0.9953}}$ & 1.6113 & 1.7137 & 1.7038 & 1.3882 & 1.3478 \\
\hline qRK & $\underline{0.0018}$ & $*$ & $\overline{2.5012}$ & 1.1285 & 2.5578 & 1.0113 & 1.7409 & 1.3373 \\
\hline $+\mathrm{LD}$ & $\underline{0.5006}$ & $<0.0001$ & $*$ & $\underline{1.3854}$ & 1.8663 & 2.2870 & 2.2465 & 1.3268 \\
\hline PLK & 0.0062 & $\underline{0.2609}$ & $\underline{\underline{0.0440}}$ & $*$ & 2.1433 & 1.4794 & 1.8481 & 0.9893 \\
\hline${ }^{\lambda} \mathrm{RD}$ & 0.0023 & $<0.0001$ & 0.0005 & $<0.0001$ & $*$ & $\underline{2.3575}$ & $\underline{2.0324}$ & 1.7889 \\
\hline${ }^{\lambda} \mathrm{RK}$ & 0.0026 & 0.4683 & $<0.0001$ & 0.0202 & $\leq 0.0001$ & $*$ & $\overline{1.5416}$ & $\underline{1.1778}$ \\
\hline${ }^{\lambda} \mathrm{LD}$ & 0.0431 & 0.0018 & $<0.0001$ & 0.0006 & $\overline{<0.0001}$ & 0.0117 & $*$ & 1.9722 \\
\hline ठૈLK & 0.0592 & 0.0642 & 0.0695 & 0.5127 & 0.0011 & $\underline{0.1947}$ & $\underline{\underline{0.0002}}$ & $*$ \\
\hline
\end{tabular}

Values above the diagonal represent the values of Fisher distance: Those underlined with a single solid line indicate distance between the two populations; Those underlined with a double solid line indicate the distance within each population. Values (italicized) below the diagonal represent the $P$-value of Fisher distance: Those underlined with a dashed line represent the left-right asymmetry detected for males of Djerba; Those underlined with a single solid line represent the left-right symmetry detected for ${ }_{+}$Djerba, 9 Kerkennah, and ${ }^{\lambda}$ Kerkennah; Those underlined with a double solid line represent the left-right asymmetry detected between the two populations: Kerkennah and Djerba.

tion: (for female and male left, $P=0.5127>0.05$ ), (for female and male right, $P=0.4683>0.05$ ).

The results of the comparison between both lots of fish (Djerba and Kerkennah) revealed a clear difference between the otoliths (left-right) of males and females ( $P$ $<0.05)$. The asymmetry (left-right) of otoliths revealed here indicates that the two populations of fish (Djerba and Kerkennah) have a different morphology of otoliths and belong to different fish stock.

The Discriminant Factor Analysis showed the projection of individuals on the two first axes (F1 and F2) (Fig. 3). Further on, these two discriminant axes explained $30.79 \%$ and $21.79 \%$ of total variation, respectively (Table $5)$. Thus, these two axes accounted for $52.58 \%$ of the total variance. The otoliths (left-right) of specimens from Djerba were separated by F1 (male) and F2 (female) axis, while the individuals of Kerkennah were differentiated by the F2 (male) axis and F5 (female) axis (F5 had a percentage of discrimination equal to $8.957 \%$ (Table 5), non-significant result with $P$-value $=0.260)$. Different statistical tests (Fisher and Mahalanobis distances) confirmed the symmetry (left-right) detected in the both male and female otoliths. This is true for the two studied sites. An exception for the males of Djerba for what we observed an asymmetry.

The otoliths (right-right) and (left-left) for Djerba and Kerkennah are separated by the axis F1. An asymmetry between the otoliths of the two populations was observed which confirmed the previous results (achieved with the Fisher and Mahalanobis tests).

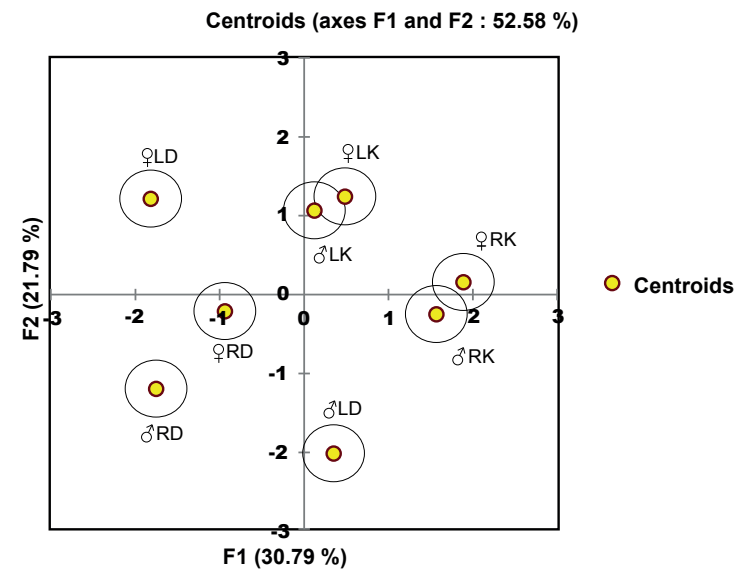

Fig. 3. Discriminant Function Analysis for two sexes and two sides of otoliths for annular seabream, Diplodus annularis

\section{DISCUSSION}

The otolith shape analysis was studied to test the possible stock discrimination existing between the two insular populations of Diplodus annularis. The results have shown that, for each population, the comparison between the left and right otoliths revealed symmetry for the otoliths of male and female of the Kerkennah population and the otoliths of female of the Djerba population.

A significant asymmetry $(<0.001)$ was only detected for the male's otolith (left-right) of the Djerba population. Such asymmetry can be explained by a genetic or environmental stress during development or a decrease in specif-

Table 5

Eigen values of the discrimination rate for populations of annular seabream, Diplodus annularis

\begin{tabular}{lrrrrrrr}
\hline & F1 & F2 & F3 & F4 & \multicolumn{1}{c}{ F5 } & \multicolumn{1}{c}{ F6 } & \multicolumn{1}{c}{ F7 } \\
\hline Eigen value & 1.7714 & 1.2537 & 0.9483 & 0.6372 & 0.5153 & 0.3767 & 0.2505 \\
Discrimination [\%] & $\underline{\mathbf{3 0 . 7 9 1 1}}$ & $\underline{\mathbf{2 1 . 7 9 1 9}}$ & 16.4827 & 11.0755 & $\underline{\mathbf{8 . 9 5 7 6}}$ & 6.5476 & 4.3537 \\
Cumulative percentage & 30.7911 & $\underline{\mathbf{5 2 . 5 8 3 0}}$ & 69.0656 & 80.1412 & 89.0988 & 95.6463 & 100.0000 \\
\hline
\end{tabular}


ic condition components like growth, fertility or survival (Panfili et al. 2005). For the Djerba population, we have also detected a sexual dimorphism.

According to Schwarzhans (1994), the function and role of the observed sexual dimorphism in the social life of the fishes is unknown. For example, within the genus Neobythites (Ophidiidae), about half of the species exhibit sexual dimorphism. An obvious explanation would be a specific sound-receiving ability designed to locate mating partners in the deep sea during reproduction period (Shuster 2009). The morphological alteration only occurs in the male otoliths (Schulz-Mirbach et al. 2010), therefore, the change for the male otoliths of fish can easily be evident and recognized (Jaramillo et al. 2014). The otoliths of female fish remain practically unchanged.

The comparisons between the two studied populations have revealed significant differences in the otolith shape. The statistical analyses have proven an asymmetry (left-right) for the otolith morphology. This may be due different factors, like the environmental parameters. In fact, there are big differences between the marine and the insular environment, the latter being characterized by the highest tides in the Mediterranean (Bernardi et al. 2014). According to Brebbi (unpublished*), the marine environment is a dispersive medium suggesting the existence of potentially significant gene flow between fish populations. This effect is acting on the marine reproduction phase. This corresponds to a gathering and homogenization which promotes mixing of fish gametes (the otoliths of different marine populations become similar and symmetrical). Trojette et al. (2014) who revealed an asymmetry (L-R) of otoliths for the Tunisian insular environment (the Island of Djerba) and symmetry (L-R) of otoliths for the Tunisian marine environment (Rafraf and Hammam Lif), confirmed this hypothesis.

The differences in habitat use by fishes (an environmental factor) may also affect the different structures as the otoliths (sagittae) (Cruz and Lombarte 2004, Lombarte and Cruz 2007, Lombarte et al. 2010). For example, Jaramillo et al. (2014) described that otoliths of four benthic fishes: Scorpaena scrofa Linnaeus, 1758; Mullus surmuletus Linnaeus, 1758; Uranoscopus scaber Linnaeus, 1758; and Synaptura lusitanica de Brito Capello, 1868 from the coast of Valencia had considerable differences in the morphology and the morphometry. This could be associated with the type of substrate where the fish is most frequently found and the habitat use (soft substrates/hard substrates/mixed substrates).

Also, environmental factors (like temperature, salinity, feeding, depth, etc.) are almost certainly the cause of geographic variations in the shape or appearance of the otolith nucleus, otolith annuli, and variations in the ratio of otolith size to fish size (Cañás et al. 2012). However, the measurements of otolith shape based on ratios of otolith radii and on the Fourier analyses in particular, had some success in distinguishing among stocks and have been assumed to be based, at least in part, on genetic dif- ferences (Capoccioni et al. 2011). In some cases, reports of stock discrimination based on otoliths morphology appear to reflect environmental differences among regions (Rakocinski et al. 2015).

Of all of the environmental factors, the most responsible one for fish, and indirectly otolith growth, is the temperature (Khemiri et al. 2005, Fablet et al. 2009). Indeed, fish are very sensitive to temperature changes and are able to respond to a change of only $0.03^{\circ} \mathrm{C}$ (Bull 1952). In this case, $L_{\infty}$ is susceptible to increase as temperature decreases (Sinovčić 2000, Basilone et al. 2004). Additionally, Taylor (1959 in Sinovčić 2000) reported that an increase of just $1{ }^{\circ} \mathrm{C}$ in the mean annual temperature reduced the $L_{\infty}$ for 29 $\mathrm{cm}$ in the Atlantic cod, Gadus morhua Linnaeus, 1758.

In addition to the environmental parameters (Aguirre and Lombarte 1999, Torres et al. 2000, Volpedo and Echeverría 2000, 2003, Gauldie and Crampton 2002, Volpedo and Fuchs 2010), also other factors have effect on the otoliths, they include ontogenetic factors (Tombari et al. 2005, Gonzalez Naya et al. 2012), physiological factors as the hearing capabilities associated with specialization in acoustic communication (Popper and Fay 1993, Paxton 2000, Lombarte and Cruz 2007), and the phylogeny (Nolf and Tyler 2006). All of those could affect the morphology, the morphometry, and the microstructure of sagittae (Volpedo and Fernández-Cirelli 2006, Volpedo et al. 2006). Other factors as the different communication strategies of fishes may also affect the different structures as the otoliths (sagittae) (Cruz and Lombarte 2004, Lombarte and Cruz 2007, Lombarte et al. 2010).

The influence of the genetics factors on growth of the otoliths cannot be disregarded. In other teleosts, differences in growth in small geographic areas (offshore/inshore) were detected for the Atlantic cod, Gadus morhua, in the Atlantic (Imsland and Jónsdottir 2003) and for the European anchovy, Engraulis encrasicolus (Linnaeus, 1758) in the Mediterranean Sea (Borsa 2002). These authors emphasized the existence of two genetically different populations for each species, a coastal population with a small size and a pelagic population with a larger size. Differences in hydrological regime between regions are generally reported as a barrier to delineate populations (Williams et al. 2009).

Moreover, Megalofonu (2006) made a comparison between growth and morphology of the otoliths with somatic growth and age in juveniles of the Atlantic bluefin tuna Thunnus thynnus (Linnaeus, 1758). This study reported that the significant statistical differences were observed between the otolith measurements and fish somatic growth. These differences were also revealed between the tested otolith variables and the fish age. Moreover, the relations between shape indexes and age revealed that the otolith morphology of bluefin tuna varied from a round shape for younger specimens ( 20 days old) to an elongated shape for older fish (129 days old).

According to Itoh et al. (2000), otolith shape of bluefin tuna is firstly spherical, then hemispherical with a flat dis- 
tal side up to the fifth increment. It seems that during the investigated life period, the otolith morphology of bluefin tuna undergoes significant dimensional change. Lagardère et al. (1995) mentioned that for other species, otolith morphology varies from a roundness of shape in larval individuals to the specific shape in adults.

In the same way, Silva et al. (2015) made the prediction of the age of juveniles of sardine, Sardina pilchardus (Walbaum, 1792), from otolith and fish morphometric characteristics. The authors revealed that morphometric variables examined, otolith weight, diameter, fish total length and weight, were linearly related to the logarithm of age in sardine juveniles being 109-280 days old.

Finally, Yadollahvand and Rahnama (2014) found that the otolith characteristics were better correlated with age than with other fish characteristics.

In our study, we made decision for a coherent sampling (the individuals have approximately the same size) and fish age classes were not determined due sampling problem, but the difference in otolith morphology between the two populations, was statistically confirmed.

\section{CONCLUSION}

This work contributes to the knowledge on the stock discrimination for Diplodus annularis, one of the commercially most important benthic fishes in Tunisia. It provides key information for studying fisheries management of this species in the investigated area.

The comparison of the otolith morphology between the two populations showed a clear difference in shape (a left-right asymmetry) of otoliths. The morphology of fish otoliths could be influenced by biotic factors related to the genotype or physiological condition of the fish, by abiotic factors (mostly temperature), or by a combination of the two parameters. Further studies are necessary to determine the origin of the otoliths shape differences and whether they are related only to environmental conditions or a genetic basis may also be responsible.

In the future research, the use of otolith shape (to determine the age of the fish) and the chemical analysis of the otoliths will be needed in order to achieve a better discrimination of stocks. Such data are of great importance for improving stock assessment. The rational stock management should be based on the population, subdivided according to phenotypic heterogeneity induced by environmental variability.

\section{REFERENCES}

Aguirre H., Lombarte A. 1999. Ecomorphological comparisons of sagittae in Mullus barbatus and M. surmuletus. Journal of Fish Biology 55 (1): 105-114.

DOI: $10.1111 /$ j.1095-8649.1999.tb00660.x

Alós J., Palmer M., Alonso-Fernández A., Morales-Nin B. 2010. Individual variability and sex-related differences in the growth of Diplodus annularis (Linnaeus, 1758). Fisheries Research 101 (1-2): 60-69.

DOI: $10.1016 /$ j.fishres.2009.09.007

Arculeo M., Lo Brutto S., Sirna-Terranova M., Maggio T., Canizzaro L., Parrinello N. 2003. The stock ge- netic structure of two Sparidae species, Diplodus vulgaris and Lithognathus mormyrus in the Mediterranean Sea. Fisheries Research 63 (3): 339-347.

DOI: $10.1016 / \mathrm{S} 0165-7836(03) 00102-4$

Ayyildiz H., Ozen O., Altin A. 2014. Growth and hatching of annular seabream, Diplodus annularis, from Turkey determined from otolith microstructure. Journal of the Marine Biological Association of the United Kingdom 94 (5): 1047-1051.

DOI: $10.1017 / \mathrm{S} 002531541400040 \mathrm{X}$

Basilone G., Guisande C., Patti B., Mazzola S., Cuttitta A., Bonanno A., Kallianiotis A. 2004. Linking habitat conditions and growth in the European anchovy (Engraulis encrasicolus). Fisheries Research 68 (1-3): 9-19.

DOI: 10.1016/j.fishres.2004.02.012

Begg G.A., Brown R.W. 2000. Stock identification of haddock Melanogrammus aeglefinus on Georges Bank based on otolith shape analysis. Transactions of the American Fisheries Society 129 (4): 935-945.

DOI: 10.1577/1548-8659(2000)129<0935:SIOHMA>2.3.CO;2

Bell J.D., Harmelin-Vivien M.L. 1983. Fish fauna of French Mediterranean Posidonia oceanica seagrass meadows. 2. Feeding habits. Tethys 11 (1): 1-14.

Bernardi G., Ramon M.L., Alva-Campbell Y., McCosker J.E., Bucciarelli G., Garske L.E., Victor B.C., Crane N.L. 2014. Darwin's fishes: Phylogeography of Galápagos Islands reef fishes. Bulletin of Marine Science 90 (1): 533-549.

DOI: $10.5343 / \mathrm{bms} .2013 .1036$

Borsa P. 2002. Allozyme, mitochondrial-DNA, and morphometric variability indicate cryptic species of anchovy (Engraulis encrasicolus). Biological Journal of the Linnean Society 75 (2): 261-269.

DOI: $10.1046 / j .1095-8312.2002 .00018 . x$

Bull H.O. 1952. An evaluation of our knowledge of fish behaviour in relation to hydrography. Rapports et procès-verbaux des réunions de la Conseil permanent international pour l'exploration de la mer 131 (7): 8-23.

Cañás L., Stransky C., Schlickeisen J., Sampedro M.P., Fariña A.C. 2012. Use of the otolith shape analysis in stock identification of anglerfish (Lophius piscatori$u s)$ in the Northeast Athlantic. ICES Journal of Marine Science 69 (2): 250-256.

DOI: $10.1093 /$ icesjms/fss006

Capoccioni F., Costa C., Aguzzi J., Menesatti P., Lombarte A., Ciccotti E. 2011. Ontogenetic and environmental effects on otolith shape variability in three Mediterranean European eel (Anguilla anguilla, L.) local stocks. Journal of Experimental Marine Biology and Ecology 397 (1): 1-7. DOI: 10.1016/j.jembe.2010.11.011

Cardinale M., Doering-Arjes P., Kastowsky M., Mosegaard H. 2004. Effects of sex, stock, and environment on the shape of known-age Atlantic cod ( $\mathrm{Ga}$ dus morhua) otoliths. Canadian Journal of Fisheries and Aquatic Sciences 61 (2): 158-167. DOI: $10.1139 / \mathrm{f03}-151$ 
Chuang G.C.-H., Kuo C.-C.J. 1996. Wavelet descriptor of planer curves: Theory and applications. IEEE Transactions on Image Processing 5 (1): 56-70.

DOI: $10.1109 / 83.481671$

Correia A.T., Pipa T., Gonçalves J.M.C., Erzini K., Hamer P.A. 2011. Insights into population structure of Diplodus vulgaris along the SW Portuguese coast from otolith elemental signatures. Fisheries Research 111 (1-2): 82-91.

DOI: 10.1016/j.fishres.2011.06.014

Crampton J.S. 1995. Elliptic Fourier shape analysis of fossil bivalves: Some practical considerations. Lethaia 28 (2): 179-186.

DOI: $10.1111 /$ j.1502-3931.1995.tb01611.x

Cruz A., Lombarte A. 2004. Otolith size and its relationship with colour pattern and sound production. Journal of Fish Biology 65 (6): 1512-1525. DOI: $10.1111 / j .0022-1112.2004 .00558 . x$

De la Paz R. 1975. Systématique et phylogenèse des Sparidae du genre Diplodus Raf., (Pisces, Teleostei). Thèse de doctorat de Troisième Cycle. Université Paris VII, France. Travaux et documents de L'O.R.S.T.O.M. No. 45.

Duarte-Neto P., Lessa R., Stosic B., Morize E. 2008. The use of sagittal otoliths in discriminating stocks of common dolphinfish (Coryphaena hippurus) off northeastern Brazil using multishape descriptors. Journal of Marine Science 65 (7): 1144-1152.

DOI: 10.1093/icesjms/fsn090

Fablet R. 2012. Des otolithes aux satellites: méthodes et applications du traitement du signal et des images pour l'observation de l'océan. Thèse HDR, France.

Fablet R., Chessel A., Carbini S., Benzinou A., De Pontual H. 2009. Reconstructing individual shape histories of fish otoliths: A new image-based tool for otolith growth analysis and modeling. Fisheries Research 96 (2-3): 148-159.

DOI: 10.1016/j.fishres.2008.10.011

Fischer W., Bauchot M., Schneider M. 1987. Fiches F.A.O d'identification des espèces pour les besoins de la pêche. Pp. 1529. In : Méditerranée et mer Noire. (eds.) Zone de pêche 37. FAO, Rome.

Gauldie R.W., Crampton J.S. 2002. An eco-morphological explanation of individual variability in the shape of the fish otolith: Comparison of the otolith of Hoplostethus atlanticus with other species by depth. Journal of Fish Biology 60 (5): 1221-1240.

DOI: $10.1111 /$ j.1095-8649.2002.tb01715.x

Gomes M.C., Serräo E., Borges M.D.F. 2001. Spatial patters of groundfish assemblages on the continental shelf of Portugal. ICES Journal of Marine Science 58 (3): 633-647.

DOI: $10.1006 /$ jmsc.2001.1052

Gonçalves J.M.S. 2000. Biologia pesqueira e dinâmica populacional de Diplodus vulgaris (Geoffr.) e Spondyliosoma cantharus (L.) (Pisces, Sparidae) na costa sudoeste de Portugal. [Fisheries biology and population dynamics of Diplodus vulgaris (Geoffr.) and Spondyliosoma cantharus (L.) (Pisces, Sparidae) on the southwest coast of Portugal.] Doctoral dissertation. Universidade do Algarve, Faro, Portugal. [In Portuguese.]

Gonzalez Naya M.J., Tombari A., Volpedo A., Gomez S.E. 2012. Size related changes in sagitta otoliths of Australoheros facetus (Pisces; Cichlidae) from South America. Journal of Applied Ichthyology 28 (5): 725755.

DOI: $10.1111 /$ j.1439-0426.2012.02006.x

Gordoa A., Molí B. 1997. Age and growth of the sparids Diplodus vulgaris, D. sargus and D. annularis in adult populations and the differences in their juvenile growth patterns in the north-western Mediterranean Sea. Fisheries Research 33 (1-3): 123-129.

DOI: $10.1016 / \mathrm{S} 0165-7836(97) 00074-\mathrm{X}$

Harmelin-Vivien M.L., Harmelin J.G., Leboulleux V. 1995. Microhabitat requirements for settlement of juvenile sparid fishes on Mediterranean rocky shores. Hydrobiologia 300/301 (1): 309-320. DOI: $10.1007 / \mathrm{BF} 00024471$

Imsland A.K., Jónsdottir Ó.D.B. 2003. Linking population genetics and growth properties of Atlantic cod. Reviews in Fish Biology and Fisheries 13 (1): 1-26. DOI: $10.1023 / \mathrm{A}: 1026373509576$

Itoh T., Shiina Y., Tsuji S., Endo F., Tezuka N. 2000. Otolith daily increment formation in laboratory reared larval and juvenile bluefin tuna Thunnus thynnus. Fisheries Science 66 (5): 834-839. DOI: $10.1046 / j .1444-2906.2000 .00135 . x$

Jaramillo A.M., Tombari A.D., Dura V.B., Rodrigo M.E., Volpedo A.V. 2014. Otolith eco-morphological patterns of benthic fishes from the coast of Valencia (Spain). Thalassas 30 (1): 57-66.

Jardas I. 1996. Jadranska ihtiofauna. [Adriatic ichthyofauna.] Školska knjiga, Zagreb, Croatia. [In Croatian.]

Khemiri S., Gaamour A., Zylberberg L., Meunier F., Romdhane M.S. 2005. Age and growth of bogue, Boops boops, in Tunisian Waters. Acta Adriatica 46 (2): 159-175.

Kınacıgil H.T., Aykol O., Metin G., Saygı H. 2000. A systematic study on the otolith characters of Sparidae (Pisces) in the Bay of Izmir (Aegean Sea). Turkish Journal of Zoology 24 (4): 357-364.

Kuhl F.P., Giardina C.R. 1982. Elliptic Fourier features of a closed contour. Computer Graphics and Image Processing 18 (3): 236-258.

DOI: $10.1016 / 0146-664 X(82) 90034-X$

Lagardère F., Chaumillon G., Amara R., Heineman G., Lago J.M. 1995. Examination of otolith morphology and microstructure using laser scanning microscopy. Pp. 7-26. In: Secor D.H., Dean J.M., Campana S.E. (eds.) Recent developments in fish otolith research. University of South Carolina Press, Colombia, SC, USA.

Lombarte A., Cruz A. 2007. Otolith size trends in marine fish communities from different depth strata. Journal of Fish Biology 71 (1): 53-76. DOI: $10.1111 /$ j.1095-8649.2007.01465.x 
Lombarte A., Palmer M., Matallanas J., Gómez-Zurita J., Morales-Nin B. 2010. Ecomorphological trends and phylogenetic inertia of otolith sagittae in Nototheniidae. Environmental Biology of Fishes 89 (3): 607-618. DOI: $10.1007 / \mathrm{s} 10641-010-9673-2$

Lychakov D.V., Rebane Y.T. 2000. Otolith regularities. Hearing Research 143 (1-2): 83-102. DOI: 10.1016/S0378-5955(00)00026-5

Matic-Skoko S., Antolic A., Kraljevic M. 2004. Ontogenetic and seasonal feeding habits of the annular seabream (Diplodus annularis L.) in the Zostera sp. beds, eastern Adriatic Sea. Journal of Applied Ichthology 20 (5): 376-381.

DOI: $10.1111 / \mathrm{j} .1439-0426.2004 .00585 . \mathrm{x}$

Matic-Skoko S., Kraljevic M., Dulcic J., Jardas I. 2007. Age, growth, maturity, mortality, and yield-per-recruit for annular sea bream (Diplodus annularis L.) from the eastern middle Adriatic Sea. Journal of Applied Ichthyology 23 (2): 152-157.

DOI: $10.1111 / \mathrm{j} .1439-0426.2006 .00816 . \mathrm{x}$

Megalofonu P. 2006. Comparison of otolith growth and morphology with somatic growth and age in youngof-the-year bluefin tuna. Journal of Fish Biology 68 (6): 1867-1878.

DOI: $10.1111 / \mathrm{j} .1095-8649.2006 .01078 . \mathrm{x}$

Mérigot B., Letourneur Y., Lecomte-Finger R. 2007. Characterization of local populations of the common sole Solea solea (Pisces, Soleidae) in the NW Mediterranean through otolith morphometrics and shape analysis. Marine Biology 151 (3): 997-1008.

DOI: $10.1007 / \mathrm{s} 00227-006-0549-0$

Mokhtarian F., Mackworth F. 1986. Scale-based description and recognition of planar curves and two-dimensional shapes. IEEE Transaction on Pattern Analysis and Machine Intelligence 8 (1): 34-43.

DOI: 10.1109/TPAMI.1986.4767750

Morat F., Betoulle S., Robert M., Thailly A.F., Biagianti-Risbourg S., Lecomte-Finiger R. 2008. What can otolith examination tell us about the level of perturbations of salmonid fish from the Kerguelen Islands? Ecology of Freshwater Fish 17 (4): 617-627. DOI: $10.1111 / \mathrm{j} .1600-0633.2008 .00313 . \mathrm{x}$

Nielsen J.R., Methven D.A., Kristensen K. 2010. Statistical discrimination method using sagittal otolith dimensions between sibling species of juvenile cod Gadus morhua and Gadus ogac from the Northwest Atlantic. Journal of Northwest Atlantic Fishery Science 43: 27-45.

DOI: $10.2960 /$ J.v43.m667

Nolf D., Tyler H. 2006. Otolith evidence concerning interrelationship of caproid zeiform and tetradontiform fishes. Bulletin de l'Institut Royal des Sciences Naturelles de Belgique 76: 147-189.

Osset E.A., Fernández M., Raga J.A., Kostadinova A. 2005. Mediterranean Diplodus annularis (Teleostei: Sparidae) and its brain parasite: Unforeseen outcome. Parasitology International 54 (3): 201-206.

DOI: 10.1016/j.parint.2005.05.002
Pajuelo J.G., Lorenzo J.M. 2001. Biology of the annular seabream, Diplodus annularis (Sparidae), in coastal waters of the Canary Islands. Journal of Applied Ichthyology 17 (3): 121-125.

DOI: $10.1111 /$ j.1439-0426.2001.00292.x

Pajuelo J.G., Lorenzo J.M. 2002. Edad y crecimiento del raspallón, Diplodus annularis (Pisces: Sparidae), en el archipiélago Canario (Atlántico centro-oriental). Ciencias Marinas 28 (1): 1-11.

DOI: $10.7773 / \mathrm{cm} . v 2811.210$

Panfili J., Durand J.D., Diop K., Gourene B., Simier M. 2005. Fluctuating asymmetry in fish otoliths and heterozygosity in stressful estuarine environments (West Africa). Marine and Freshwater Research 56 (5): 505-516. DOI: $10.1071 / \mathrm{MF} 04138$

Parisi-Baradad V., Lombarte A., Garcia-Ladona E., Cabestany J., Piera J., Chic O. 2005. Otolith shape contour analysis using affine transformation invariant wavelet transforms and curvature scale space representation. Marine and Freshwater Research 56 (5): 795-804. DOI: $10.1071 / \mathrm{MF} 04162$

Platt C., Popper A.N. 1981. [Chapter 1] Fine structure and function of the ear. Pp. 3-38.

DOI: 10.1007/978-1-4615-7186-5_1. In: Tavolga W.N., Popper A.N., Fay R.R. (eds.) Hearing and sound communication in fishes. New York. DOI: $10.1007 / 978-1-4615-7186-5$

Paxton J.R. 2000. Fish otoliths: Do sizes correlate with taxonomic group, habitat and/or luminescence? Philosophical Transactions of the Royal Society of London B 355 (1401): 1299-1303.

DOI: $10.1098 /$ rstb.2000.0688

Pita C., Gamito S., Erzini K. 2002. Feeding habits of the gilthead seabream (Sparus aurata) from the Ria Formosa (southern Portugal) as compared to the black seabream (Spondyliosoma cantharus) and the annular seabream (Diplodus annularis). Journal of Applied Ichthyology 18 (2): 81-86.

DOI: $10.1046 /$ j.1439-0426.2002.00336.x

Ponton D. 2006. Is geometric morphometrics efficient for comparing otolith shape of different fish species? Journal of Morphology 267 (6): 750-757.

DOI: $10.1002 /$ jmor. 10439

Popper A.N., Fay R.R. 1993. Sound detection and processing by fish: Critical review and major research questions. Brain, Behavior and Evolution 41 (1): 14-38. DOI: $10.1159 / 000316111$

Rakocinski C.F., Comyns B.H., Peterson M.S., Shiller A.M. 2015. Regional patterns in the otolith chemistry of juvenile spotted sea trout (Cynoscion nebulosus) differ under contrasting hydrological regimes. Open Fish Science Journal 8: 1-12.

DOI: 10.2174/1874401X01508010001

Ribeiro J., Bentes L., Coelho R., Gonçalves J.M.S., Lino P.G., Monteiro P., Erzini K. 2006. Seasonal, tidal and diurnal changes in fish assemblages in the Ria Formosa lagoon (Portugal). Estuarine, Coastal and Shelf Science 67 (3): 461-474.

DOI: $10.1016 /$ j.ecss.2005.11.036 
Rosecchi E. 1987. L'alimentation de Diplodus annualris, Diplodus sargus, Diplodus vulgaris et Sparus aurata (Pisces, Sparidae) dans le golfe du Lion et les lagunes littorales. Revue des Travaux de l'Institut des Pêches Maritimes 49 (3-4): 125-141.

Sadighzadeh Z., Valinassab T., Vosugi G., Motallebi A.A., Fatemi M.R., Lombarte A., Tuset V.M. 2014. Use of otolith shape for stock identification of John's snapper, Lutjanus johnii (Pisces: Lutjanidae), from the Persian Gulf and the Oman Sea. Fisheries Research 155: 59-63.

DOI: $10.1016 /$ j.fishres.2014.02.024

Schulz-Mirbach T., Ladich F., Riesch R., Plath M. 2010. Otolith morphology and hearing abilities in cave- and surface-dwelling ecotypes of the Atlantic molly, Poecilia mexicana (Teleostei: Poeciliidae). Hearing Research 267 (1-2): 137-148.

DOI: $10.1016 /$ j.heares.2010.04.001

Schwarzhans W. 1994. Sexual and ontogenetic dimorphism in otoliths of the family Ophidiidae. Cybium 18 (1): 71-98.

Shuster S.M. 2009. Sexual selection and mating systems. Proceedings of the National Academy of Sciences of the United States of America 106 (Suppl. 1): 1000910016.

DOI: $10.1073 /$ pnas.0901132106

Silva A.V., Meneses I., Silva A. 2015. Predicting the age of sardine juveniles (Sardina pilchardus) from otolith and fish morphometric characteristics. Scientia Marina 79 (1): $35-42$.

DOI: $10.3989 /$ scimar.04143.16A

Sinovčić G. 2000. Anchovy, Engraulis encrasicolus (Linnaeus, 1758): Biology, population dynamics and fisheries case study. Acta Adriatica 41 (1): 3-53.

Sousa P., Azevedo M., Gomes M.C. 2005. Demersal assemblages off Portugal: Mapping, seasonal, and temporal patterns. Fisheries Research 75 (1-3): 120-137. DOI: 10.1016/j.fishres.2005.03.012

Summerer M., Hanel R., Sturmbauer C. 2001. Mitochondrial phylogeny and biogeographic affinities of sea breams of the genus Diplodus (Sparidae). Journal of Fish Biology 59 (6): 1638-1652.

DOI: 10.1111/j.1095-8649.2001.tb00227.x

Tombari A.D., Volpedo A.V., Echeverría D.D. 2005. Desarrollo de la sagitta en juveniles y adultos de Odontesthes argentinensis (Valenciennes, 1835) y Odontesthes bonariensis (Valenciennes, 1835) de la provincia de Buenos Aires, Argentina (Teleostei: Atheriniformes). Revista Chilena de Historia Natural 78 (4): 623-633. DOI: $10.4067 / \mathrm{S} 0716-078 X 2005000400003$
Torres G.J., Lombarte A., Morales-Nin B. 2000. Variability of the sulcus acusticus in the sagittal otolith of the genus Merluccius. Fisheries Research 46 (1-3): $5-13$. DOI: $10.1016 / \mathrm{S} 0165-7836(00) 00128-4$

Tortonese E. 1975. Osteichthyes pesci ossei (Parte seconda). [Osteichthyes bony fishes (Part Two).] Calderini, Bologna, Italy. [In Italian.]

Trojette M., Fatnassi M., Ben Alaya H., Mahouachi N.H., Chalh A., Quignard J.-P., Trabelsi M. 2014. Applying sagitta otolith shape in the discrimination of fish populations Scorpaena porcus (Linnaeus, 1758) (Scorpaenidae) in the Tunisian coasts. Cahiers de Biologie Marine 55 (4): 499-506.

Volpedo A., Echeverría D.D. 2000. Catálogo y claves de otolitos para la identificación de peces del mar argentino. 1. Peces de importancia económica. Dunken, Buenos Aires.

Volpedo A., Echeverría D.D. 2003. Ecomorphological patterns of the sagitta in fish on the continental shelf off Argentine. Fisheries Research 60 (2-3): 551-560. DOI: $10.1016 / \mathrm{S} 0165-7836(02) 00170-4$

Volpedo A.V., Fernández Cirelli A. 2006. Otolith chemical composition as a useful tool for sciaenid stock discrimination in south-western Atlantic. Scientia Marina 70 (2): 325-334.

DOI: $10.3989 /$ scimar.2006.70n2325

Volpedo A.V., Fuchs D.V. 2010. Ecomorphological patterns of the lapilli of Paranoplatense siluriforms (South America). Fisheries Research 102 (1-2): 160-165. DOI: 10.1016/j.fishres.2009.11.007

Volpedo A.V., Miretzky P., Fernández Cirelli A. 2006. Stocks pesqueros de Cynoscion guatucupa y Micropogonias furnieri (Pisces, Sciaenidae) en la costa atlántica de Sudamérica: comparación entre métodos de identificación. Memoria de la Fundación La Salle de Ciencias Naturales 66 (165): 115-130.

Williams J.E., Haak A.L., Neville H.M., Colyer W.T. 2009. Potential consequences of climate change to persistence of cutthroat trout populations. North American Journal of Fisheries Management 29 (3): 533-548. DOI: $10.1577 / \mathrm{M} 08-072.1$

Yadollahvand R., Rahnama B. 2014. The age determination of black pomfret (Parastromateus niger), based on otolith cross sections in Iranian coast of Oman Sea. Journal of Aquaculture Research and Development 5 (5): $1-4$

DOI: $10.4172 / 2155-9546.1000261$

Received: 26 May 2015

Accepted: 29 October 2015

Published electronically: 31 December 2015 